\title{
Peaceful Use of the Sea and Military Intelligence Gathering in the EEZ
}

\author{
Keyuan Zou
}

The 1982 United Nations Convention on the Law of the Sea (LOS Convention) ${ }^{1}$ is regarded as a global ocean code governing maritime zones and human activities therein. According to it, maritime space is divided into several zones either under or beyond national jurisdiction of a coastal State: internal waters within the baselines are treated the same as the land territory of a State and under the full sovereignty of that State; territorial seas are also under the sovereignty of the coastal State only subject to the provisions of the Los Convention allowing foreign ships to exercise the right of innocent passage; exclusive economic zone (EEZ) which extends outward 200 nautical miles from the baselines where the coastal State enjoys sovereign rights to natural resources and national jurisdiction over certain maritime activities including marine scientific research; the legal status of the continental shelf is similar to that of the EEZ, but for broad continental shelf countries, they may claim it up to 350 nautical miles; high seas which are open to all; and the international seabed which is now under the governance of the International Seabed Authority.

The concept of the EEZ is relatively new in the international law of the sea in comparison with the territorial sea regime and has some unique characteristics. Thus, it is defined as a maritime zone sui generis. Article 56 of the Los Convention provides that a coastal State has "sovereign rights for the purpose of exploring and exploiting, conserving and managing the natural resources" and other activities for the economic exploration and exploitation, as well as jurisdiction with regard to "the establishment and use of artificial islands, installations and structures, marine scientific research, and the protection and preservation of the marine environment". However, some high seas rights, including the freedom of navigation and overflight, are preserved in the EEz. Furthermore, such rights include "other international lawful uses of the sea

1 United Nations Convention on the Law of the Sea, opened for signature 10 December 1982, 21 ILM 1261 (entered into force 16 November 1994).

(C) KEYUAN ZOU, 2019 | DOI:10.1163/9789004379633_009

This is an open access article distributed under the terms of the prevailing CC-BY-NC License at the time of publication. 
related to these freedoms, such as those associated with the operation of ships, aircraft and submarine cables and pipelines", ${ }^{2}$ which has invited controversial interpretations in terms of military uses including military intelligence gathering in the EEZ of another coastal State.

Recent maritime incidents having occurred in East Asia, for example, the EP-3E Spy Airplane Incident in $2001,{ }^{3}$ have raised a number of legal issues in the context of the development of the law of the sea, particularly of the EEZ regime. Because the EEZ regime is relatively new, it is quite understandable that many new issues will arise during its implementation after the entry into force of the Los Convention.

\section{Peaceful Use of the Seas and Foreign Military Activities in the EEZ}

According to the Los Convention, all the seas in the world shall be used peacefully, and any threat or use of force against the territorial integrity or political independence of any State, or in any other manner inconsistent with the principles of international law embodied in the Charter of the United Nations shall be prohibited. ${ }^{4}$ From this basic legal principle, military activities including military intelligence gathering with threatening potentials should not be carried out in the EEzs of other countries.

2 See Art. 58, Los Convention.

3 On 1 April 2001, while a U.S. EP-3E Aries II airplane was conducting espionage activities near the Chinese coast in the South China Sea, it was intercepted by two Chinese F- 8 fighter jets and then collided with one of the jets. The damaged Chinese jet crashed into the water and the pilot died. The damaged American airplane made an emergency landing in China's Hainan Island at Lingshui and all the crewmembers were safe. The incident immediately became a diplomatic issue between China and the United States. China accused the United States of encroaching on China's territorial sovereignty and of violation of international law as well as of relevant Chinese laws, and demanded an apology and compensation from the American side. The United States responded that the reconnaissance airplane operated outside China's territorial waters and that the airplane landed in distress. For that reason, the United States refused to render an apology; and instead demanded China to immediately return the American crew and the airplane. After several rounds of diplomatic contacts, the United States finally sent a letter to China on 11 April 2001, expressing its sincere regret over the Chinese missing pilot and aircraft and used the word "sorry" for their loss. The letter also used the word "sorry" for the American airplane's entering of China's airspace and landing without verbal clearance. On the next day, China allowed all 24 crewmembers to leave China. However, the American damaged spy airplane did not leave China until 3 July 2001 after it had been dismantled and packed. The Chinese side asked for one million US dollars for the costs relating to the aircraft but the Americans only offered the amount of 34,567 US dollars which was refused by the Chinese. For related information, see, State Jurisdiction and Jurisdictional Immunities: Aerial Incident off the Coast of China, 95 AJIL 631-633 (2001).

4 See Art. 301, Los Convention. 
According to one scholar, military use of oceans consists of two categories: movement rights and operational rights. The former embraces the notion of mobility and includes such legal rights as transit passage through straits used for international navigation, innocent passage in territorial seas and archipelagic waters, and high seas freedom of navigation and overflight, and the latter includes such activities as task force maneuvering, anchoring, intelligence collection and surveillance, military exercises, ordnance testing and firing, and hydrographic and military surveys. ${ }^{5}$ For the purpose of this article, military activities refer to those activities in the second category as defined above, i.e., other than simple navigation or overflight.

As we know, there is a controversy on whether the conduct of military activities in the EEZ of another country is legitimate. Some States may invoke Article 58(1) of the Los Convention to justify their military activities in other countries' EEz. The provision reads: "[i]n the exclusive economic zone, all States, whether coastal or land-locked, enjoy, subject to the relevant provisions of this Convention, the freedoms referred to in Article 87 of navigation and overflight and of the laying of submarine cables and pipelines, and other internationally lawful uses of the sea related to these freedoms, such as those associated with the operation of ships, aircraft and submarine cables and pipelines, and compatible with the other provisions of this Convention". Freedoms on the high seas provided in Article 87 are thus applicable to the EEZ as long as they are not contrary to other provisions of the LOs Convention. According to maritime powers such as the United States, the term freedoms "associated with the operation of ships, aircraft" implies the legality of naval maneuvers in a foreign EEz. ${ }^{6}$ One view even considers military exercises, aerial reconnaissance and all other activities of military aircraft freedom of high seas if due regard is paid to the rights and interests of third States. ${ }^{7}$ As advocated, since the Los Convention mainly provides the rights of navigation and overflight, while keeping silent on the rights of military activities, maritime superpower must defend and enforce such rights for its security interests.

5 Charles E. Pirtle, Military Uses of Ocean Space and the Law of the Sea in the New Millennium, 31 Ocean Development and International Law 8 (2000).

6 See Boleslaw Adam Boczek, Peacetime Military Activities in the Exclusive Economic Zone of Third Countries, 19 Ocean Development and International LaW $45^{\circ}$ (1988).

7 Kay Hailbronner, Freedom of the Air and the Convention on the Law of the Sea, 77 AJIL 503 (1983). A US operational commander opined that the EEZ regime "does not permit the coastal state to limit traditional non-resources related high seas activities in this EEZ, such as task force maneuvering, flight operations, military exercises, telecommunications and space activities, intelligence and surveillance activities, marine data collection, and weapons' testing and firing". Walter F. Doran, An Operational Commander's Perspective on the 1982 LOS Convention, 10 International Journal of Marine and Coastal LaW 341 (1995). 
The Los Convention does not mention military use so that it becomes a gray area which leads to different interpretations. This no-mention is criticized as one of the major defects in the new Los Convention. On the other hand, it is argued that without an express mention in the Convention, military use is hardly regarded as one of such lawful uses. However, such argument may not be convincing. According to a fundamental legal principle, nothing is illegal if there is no law to make it so. Following this, military use is not prohibited since there is no such prohibition in the LOS Convention. Second, as the LOS Convention affirms that matters which are not regulated under it should be continually governed by general international law including customary law. If it is traced back to look at history, military activities were consistently allowed under customary international law, though in the implied form. Third, it is admitted that there is a difficulty in inferring that the establishment of the EEZ has limited foreign military operations other than pure navigation and communication from the text and legislative history of Article $5^{8}$ of the Los Convention. ${ }^{8}$

The allowance of military activities under international law does not mean that they can be conducted in the EEz without any regulation. It should be borne in mind that the circumstances now are fundamentally different from those in the past. There was and still remains no controversy regarding the military activities conducted in the high seas which was and is open to all. The EEZ is different from the high seas in that it is an area under national jurisdiction. While military activities are allowed there, the factor of national jurisdiction must be taken into account. There should be some kind of checkand-balance mechanism for foreign military activities in the EEz. It is hard to understand the logic of the argument that while marine scientific research in the EEZ is subject to the consent of the coastal State, military activities can be conducted freely without any check by the coastal State. On the other hand, even if the military use is an internationally lawful use, it can be argued according to the Los Convention that it is limited to navigation and overflight, and other rights as provided in Article 87 of the Convention. This can be seen from some domestic EEz legislations, such as Suriname's, as it provides, all nations, with the observance of the international law, enjoy: "... 4. Freedom to exercise internationally recognized rights in connection with navigation and communication". 9

8 Francesco Francioni, Peacetime Use of Force, Military Activities, and the New Law of the Sea, 18 Cornell International LaW Journal 216 (1985).

9 Art. 5 of Law Concerning the Extension of the Territorial Sea and the Establishment of a Contiguous Economic Zone of 11 June 1978, in Division for OCEAN Affairs AND the Law of the Sea, Office of Legal Affairs, United Nations, The Law of the Sea: National Legislation on the Exclusive Economic Zone 351 (1993). 
In practice, coastal States, including Bangladesh, ${ }^{10}$ Brazil, Cape Verde, India, ${ }^{11}$ Pakistan, ${ }^{12}$ and Uruguay ${ }^{13}$ explicitly restrict unapproved military exercises or activities in or over their EEzs conducted by other countries. According to Brazilian law, military exercises or maneuvers, in particular those that imply the use of weapons or explosives, can only be carried out with the consent of the Brazilian Government. ${ }^{14}$ Brazil is perhaps the most adamant country which strictly regulates foreign military activities in its EEz. As early as December 1982 when Brazil signed the Los Convention, it made a statement of this kind which was reiterated several times afterwards. The United States reacted to it on each occasion by protesting against Brazil's restrictions and stating its reservation of military exercises in Brazil's EEZ as internationally lawful uses

Honduras' law contains a similar provision (Art. 2 of Decree No. 921 of 13 June 1980 on the Utilization of Marine Natural Resources), see Division for Ocean Affairs ANd the Law of the Sea, Office of Legal Affairs, United Nations, ibid., at 129.

10 The Bangladesh Declaration states: “The Government of the People's Republic of Bangladesh understands that the provisions of the Convention do not authorize other States to carry out in the exclusive economic zone and on the continental shelf military exercise or manoeuvres, in particular, those involving the use of weapons or explosives, without the consent of the coastal State". Available at http://www.un.org/Depts/los/convention agreements/convention_declarations.htm.

11 The Indian Declaration states: "The Government of the Republic of India understands that the provisions of the Convention do not authorize other States to carry out in the exclusive economic zone and on the continental shelf military exercises or manoeuvres, in particular those involving the use of weapons or explosives without the consent of the coastal State". Available at http://www.un.org/Depts/los/convention_agreements/ convention_declarations.htm.

12 The Pakistani Declaration states: "It is the understanding of the Government of the Islamic Republic of Pakistan that the provisions of the Convention on the Law of the Sea do not in any way authorize the carrying out in the exclusive economic zone and in the continental shelf of any coastal State military exercises or manoeuvres by other States, in particular where the use of weapons or explosives is involved, without the consent of the coastal State concerned". Available at http://www.un.org/Depts/los/convention_ agreements/convention_declarations.htm.

13 The Uruguay Declaration states: "In the exclusive economic zone, enjoyment of the freedom of international communication in accordance with the way it is defined and in accordance with other relevant provisions of the Convention excludes any non-peaceful use without the consent of the coastal State - for instance, military exercises or other activities which may affect the rights or interests of that State; and it also excludes the threat or use of force against the territorial integrity, political independence, peace or security of the coastal State". Available at http://www.un.org/Depts/los/convention_agreements/ convention_declarations.htm.

14 Article 9 of the Act concerning the Territorial Sea, the Contiguous Zone, the Exclusive Economic Zone and the Continental Shelf of Brazil and other provisions: Act No. 8617 of 4January 1993, in Division for Ocean Affairs and the LaW of the Sea, Office of Legal Affairs, United Nations, supra note 9, at 38. 
of the ocean. ${ }^{15}$ The other typical country is Iran which also lays down laws restricting foreign military activities in its EEZ by stipulating that "[f]oreign military activities and practices, collection of information and any other activity inconsistent with the rights and interests of the Islamic Republic of Iran in the exclusive economic zone and the continental shelf are prohibited". Because of this legal provision, there was a diplomatic row between Iran and the United States. The United States lodged a protest against it by stating that the prohibition of military activities contravenes international law and the United States reserves its rights in this regard. In reply to the United States protest, the Iranian diplomatic note states that due to the multiplicity of economic activities, it is possible that such activities, for which the coastal State enjoys sovereign rights, could be harmed by military practices and maneuvers; accordingly, those practices which affect the economic activities in the EEZ and the continental shelf are thus prohibited. It is interesting to note that the Iranian explanation does not deny the right of foreign military activities in the EEZ and the only reason for their prohibition results in their possible harm to economic activities there.

Relating to East Asia, it is worthy to mention Malaysia's position. As stated, "the Malaysian Government also understands that the provisions of the Convention do not authorize other States to carry out military exercises or manoeuvres, in particular those involving the use of weapons or explosives in the EEZ without the consent of the coastal State". ${ }^{16}$ According to a prominent Malaysian scholar, there are three reasons to explain Malaysia's position. First, in Malaysia's view, there is no law that prohibits coastal State jurisdiction over foreign military activities in the EEz. Moreover, unauthorized foreign military activities can undermine a coastal State's security, particularly if they are nonpeaceful in nature. Second, the Los Convention is a treaty where the provision on foreign military activities in the EEZ is a new and controversial concept, rather than customary international law. Third, the provision on military activities in the EEZ is not consistent with the principle of peaceful uses of the sea. Malaysia views foreign military activities in its EEZ as undermining and threatening its security as well. ${ }^{17}$

15 For details, see J. Ashley Roach and Robert W. Smith, United States Responses to Excessive Maritime Claims 409-413 (1996).

16 Malaysian Declaration, available at http://www.un.org/Depts/los/convention_agree ments/convention_declarations.htm.

17 See BA Hamzah, Military Activities in the EEZ: Preliminary Views from Malaysia, in SHIcun Wu and Keyuan Zou (eds.), Securing the Safety of Navigation in East Asia: Legal and Political Dimensions (2015). 
The regulations above are made under the rationale that military activities are inherently potential threats to peace and good order of the coastal States. While such regulations are understandable, it should be borne in mind that not all military activities are threatening. Contrarily, some military activities, such as the activities undertaken by the UN peacekeeping forces, are indispensable to maintain peace and good order. In the same thinking, some civilian activities may be threatening and this can be illustrated by a severe marine pollution accident caused by a civilian activity or illegal fishing in the EEz. In such context, what we should look into is not the form of a certain activity, but its nature. If a military activity is threatening in nature and with clear bad intention and/or in a hostile manner, it should be banned in the EEz. Otherwise, it can be allowed under certain conditions laid down by the coastal State, similar to the marine scientific research regime under the Los Convention. There is no reason why the coastal State is prevented from regulating foreign military activities in its EEZ while it is allowed to regulate foreign marine scientific research there.

There is a discrepancy regarding the concept of the EEz between the legal term and the operational term. The United States navy divides the ocean into two categories: national waters and international waters, for operational and mobility purposes. ${ }^{18}$ The EEz is accordingly categorized as "international waters". ${ }^{19}$ However, it must be pointed out that it is only an expression for operational purposes, thus in no way affecting the legal nature of the EEZ as a maritime zone within national jurisdiction under the Los Convention.

It is worth mentioning that the East-West Center once organized several workshops on "military and intelligence gathering activities in the EEZ". The launch of this series of workshops was triggered by the EP-3 Incident between China and the United States. The first one was held in Bali, Indonesia in June

18 National waters include internal waters, territorial seas and archipelagic waters, and international waters include contiguous zones, EEZ, high seas and security zones. See DEpartment of the Navy, The Commander's Handbook on the LaW of Naval Operations 1-4, 1-6 (1995).

19 The term "international waters" is even questioned by retired naval officials. See Paul (Pete) Pedrozo, Preserving Navigational Rights and Freedoms: The Right to Conduct Military Activities in China's Exclusive Economic Zone, 9 Chinese Journal of InTERnaTIONAL LAW 19 (2010), (“continued reliance on the term 'international waters' by the United States muddies the waters and unnecessarily allows China to divert attention from the legitimacy of the US position by arguing that the United States does not know the difference between the EEZ and the high seas. The United States should therefore cease to use the term 'international waters' when referring to its lawful military activities in the EEZ".) 
2002, which focused on identifying disagreements and contrasting positions as well as on areas of possible mutual understanding and agreement. ${ }^{20}$ The Tokyo Meeting in February 2003 acknowledged that with the technology advances in the EEZs, intelligence gathering activities would increase. ${ }^{21}$ The Honolulu Meeting in December 2003 went further and some guidelines for military and intelligence gathering activities in the EEzs were drafted, based on the disagreement between maritime powers and developing coastal countries. ${ }^{22}$ According to the Guidelines drafted by the study group, "ships and aircraft of a State undertaking military activities in the EEZ of another State have the obligation to use the ocean for peaceful purposes only, and to refrain from the threat or use of force, or provocative acts, such as stimulating or exciting the defensive systems of the coastal State; collecting information to support the use of force against the coastal State; or establishing a 'sea base' within another State's EEZ without its consent. The user State should have due regard for the rights of others to use the sea including the coastal State and comply with its obligations under international law".23 Furthermore, "warships or aircraft of a State intending to carry out a major military exercise in the EEZ of another State should inform the coastal State and others through a timely navigational warning of the time, date and areas involved in the exercise, and if possible, invite observers from the coastal State to witness the exercise". ${ }^{24}$ As for military surveying, the Guidelines provides that "maritime surveillance may be conducted by states for peaceful purposes in areas claimed by other states as EEZ and should not prejudice the jurisdictional rights and responsibilities of the coastal state within its EEz". ${ }^{25}$ Unfortunately, these constructive guidelines are rejected by the United States despite the involvement of American scholars in the drafting process.

20 For details, see East-West Center, Military and Intelligence Gathering ACtivities in Exclusive Economic Zones: Consensus and Disagreement: A Summary of the Bali Dialogue (2002).

21 For details, see East-West Center, The Regime of the Exclusive Economic Zones: Issues And Responses: A Report of the Tokyo Meeting (2003).

22 See Hasjim Djalal, Alexander Yankov and Anthony Bergin, Draft guidelines for military and intelligence gathering activities in the $E E Z$ and their means and manner of implementation and enforcement, 29 (2) MARINE POLICY 175-183 (2005).

23 See, Guidelines for Navigation and Overflight in the Exclusive Economic Zone, 16 September 2005, Tokyo, available at http://www.sof.or.jp/en/report/pdf/200509_20051205_e.pdf.

24 Ibid.

25 Ibid. 
There is another grey area, which is also related to military intelligence gathering in the EEZ, i.e., hydrographic surveying when it is undertaken for military purposes. The International Hydrographic Bureau defines "hydrographic surveying" as "a survey having for its principal purpose the determination of data relating to bodies of water. A hydrographic surveying may consist of the determination of one or several of the following classes of data: depth of water, configuration and nature of the bottom; directions and force of currents; heights and times of tides and water stages; and location of topographic features and fixed objects for survey and navigation purposes". ${ }^{26}$

Although some wordings like "survey activities" and "hydrographic survey" appear in the Los Convention, the Convention does not contain any provision specifically governing this kind of marine activity. The grey and ambiguous area is further widened in the context of the relevant provisions of the LOS Convention regarding marine scientific research (MSR).

The LOS Convention contains a whole part on MSR (Part XIII) with 6 sections and 28 provisions. It recognises the right of all States and competent international organisations in the world to conduct MSR in accordance with the Convention (Art. 238). MSR, as a good thing for human beings, should be promoted, and international cooperation in this respect is much appreciated. The conduct of MSR should follow the four principles below:

(a) MSR should be conducted exclusively for peaceful purposes;

(b) MSR should be conducted with appropriate scientific methods and means compatible with the Los Convention;

(c) MSR should not unjustifiably interfere with other legitimate uses of the sea compatible with the Los Convention and should be duly respected in the course of such uses; and

(d) MSR should be conducted in compliance with all relevant regulations adopted in conformity with the Los Convention including those for the protection and preservation of the marine environment (Art. 240).

The LOS Convention sets forth different regulations regarding MSR conducted in different sea zones. For the territorial sea and internal waters, the coastal State has the exclusive right to regulate, authorise and conduct MSR. Without the express consent from the coastal State, MSR to be conducted by foreigners

26 ino, Hydrographic Dictionary (1994), available at http://www.iho.int/iho_pubs/ standard/S-32/S-32-eng.pdf. 
are not allowed therein (Art. 245). Such a provision is understandable since the territorial sea is commonly regarded as part of the territory of the coastal State.

For the EEz and the continental shelf, the legal governance in the LOS Convention differs from that for the territorial sea. The coastal State, for the purpose of exercising its jurisdiction, has the right to regulate, authorise and conduct MSR in the EEZ and on the continental shelf. MSR should be conducted with the consent of the coastal State (Art. 246). It is noted that the word "express" does not appear here in the provisions for the MSR in the EEZ and continental shelf. This is because the legal status of the EEZ and the continental shelf is different from that of the territorial sea in that the coastal State can only exercise sovereign rights and jurisdiction over its EEZ and continental shelf, but not full sovereignty. However, there are still a number of requirements contained in the Los Convention to protect the interests and respect the legitimate rights of the coastal State. The foreign related MSR projects in the EEZ and on the continental shelf of a coastal State should be carried out "exclusively for the peaceful purposes and in order to increase scientific knowledge of the marine environment for the benefit of all mankind",27 and should not unjustifiably interfere with activities undertaken by a coastal State in the exercise of its sovereign rights and jurisdiction under the Los Convention. ${ }^{28}$

The researching State or international organisation bears the duty to comply with certain conditions to conduct its MSR. First, the research conductor has the duty to provide to the coastal State detailed information on the MSR to be conducted in the EEZ or on the continental shelf of the coastal State not less than six months in advance (Art. 248). Second, the conductor has the duty to comply with the following conditions: "(a) ensure the right of the coastal State, if it so desires, to participate or be represented in the marine scientific research project, especially on board research vessels and other craft or scientific research installations, when practicable, without payment of any remuneration to the scientists of the coastal State and without obligation to contribute towards the costs of the project; (b) provide the coastal State, at its request, with preliminary reports, as soon as practicable, and with the final results and conclusions after the completion of the research; (c) undertake to provide access for the coastal State, at its request, to all data and samples derived from the marine scientific research project and likewise to furnish it with data which may be copied and samples which may be divided without detriment to their scientific value; (d) if requested, provide the coastal State with an assessment

27 Art. 246 (3), Los Convention.

28 Art. 246 (8), Los Convention. 
of such data, samples and research results or provide assistance in their assessment or interpretation; (e) ensure, subject to paragraph 2, that the research results are made internationally available through appropriate national or international channels, as soon as practicable; (f) inform the coastal State immediately of any major change in the research programme; $(\mathrm{g})$ unless otherwise agreed, remove the scientific research installations or equipment once the research is completed". 29

The coastal State has the right to require the suspension or cessation of any MSR activities in case of any non-compliance with the provisions in Articles 248 and 249 of the Los Convention (Art. 253). On the other hand, the coastal State should not make excessive measures beyond the authorisation under the Los Convention, otherwise it may be responsible and liable for them and should provide correspondent compensation. ${ }^{30}$ It should be noted that under the Los Convention, any MSR activity should not constitute the legal basis for any claim to any part of the marine environment or its resources (Art. 241). This is particularly important for disputed sea areas which are claimed by two or more countries. In practice, countries usually tend to maximize their use of evidences including MSR activities to justify their relevant territorial claims to a particular sea area or its resources.

It is clear from the above that the MSR regime focuses mainly on the MSR in the EEZ and on the continental shelf. The related provisions are most delicate and complex in comparison with the provisions on MSR in the territorial sea, or archipelagic waters. That part of the provisions were mostly debated during the UNCLOS III, reflecting the compromise between the advanced countries with strong MSR capability and the developing countries which are relatively poor and inadequate for sound MSR.

The LOS Convention contains no definition on MSR. During the UNCLOS III, the Chairman of the Third Committee included the flowing definition in the ISNT, Part III: "Marine scientific research means any study or related experimental work designed to increase man's knowledge of the marine environment". ${ }^{31}$ However, such a definition was not finally included in the adopted Convention. The United States tried to define MSR as "the general term most often used to describe those activities undertaken in the ocean and coastal waters to expand scientific knowledge of the marine environment

\footnotetext{
29 Art. 249 (1), Los Convention.

$30 \quad$ Art. 263 (2), Los Convention.

31 See Alfred H.A. Soons, Marine Scientific Research and the Law of the Sea 123 (1982).
} 
and its processes". ${ }^{32}$ Some scholars have tried to distinguish fundamental MSR from applied MSR in terms of application of the LOS Convention: whereas the former has to be granted in normal circumstances, the latter is subject to the coastal State's full discretion. ${ }^{33}$ However, such a distinction does not seem to provide any help to clarify the unclear situation, and even the distinction itself causes problems since there is no clear-cut demarcation to define an MSR as fundamental or applied. The ambiguity of the MSR definition may cause problems for researching States, but have little adverse impact on costal States since they have a great discretionary power to decide whether an MSR is acceptable under Article 246 of the Los Convention.

It is acknowledged that MSR and hydrographic surveying overlap to some extent. There is a reference in the Los Convention which may help to some extent clarify the grey area existing between MSR and hydrographic surveying. According to Article $19(2)(j)$, "the carrying out of research or survey activities" is prohibited when a foreign vessel exercises the right of innocent passage through the territorial sea. This legal expression contains the following two meanings: on the one hand, it distinguishes "research activity" from "survey activity", but on the other these two activities are given the same treatment.

In State practice, while the United States and the United Kingdom take the view that military hydrographic surveying is part of the freedoms of high seas related to "international lawful uses of the sea", Australia and Canada "are understood to seek permission of the coastal State before conducting hydrographic surveying in the EEZ of that State". ${ }^{34}$ Some coastal countries like China hold the view that hydrographic surveying is part of MSR and have specific laws governing both MSR and hydrographic surveying.

In 2001, USNS Bowditch, an American military surveillance vessel, entered into China's EEz in the Yellow Sea three times to carry out hydrographic surveying and was confronted by Chinese Marine Surveillance vessels. Chinese monitoring vessels followed the American ship and attempted to disrupt its operations. Even in one time a Chinese warship forced the Bowditch to leave the Chinese EEz. ${ }^{35}$ After the Bowditch Incident, China has tightened its control of hydrographic surveying in the maritime zones of its national jurisdiction.

32 J. Ashley Roach and Robert W. Smith, United States Responses to ExcesSive Maritime Claims 425 (1996).

33 Wolf Plesman and Volker Röben, Marine Scientific Research: State Practice versus Law of the Sea? in Rüdiger Wolfrum (ed.), LaW of the Sea at the Crossroads: The Continuing Search for a Universally Accepted Regime 375 (1991).

34 Sam Bateman, Hydrographic Surveying in the EEZ: Differences and Overlaps with Marine Scientific Research, 29 (2) MARINe PoliCY 170 (2005).

35 See John Leicester, Chinese Chase US Ship;Jet Crash Part of Spy Game, He rald Sun, 4 April 2001, at 32; cited in Captain George V. Galdorisi and Commander Alan G. Kaufman, Military 
One move was to revise the 1992 Law of Surveying and Mapping. The original provision governing foreign surveying activities has been revised as "Surveying and mapping to be conducted within the territory and other sea areas under the jurisdiction of the People's Republic of China by a foreign organization or individual must be approved by the competent department of surveying and mapping administration under the State Council together with the competent department of surveying and mapping administration of the Army, and shall comply with relevant laws and administrative rules and regulations of the People's Republic of China. A foreign organization or individual that conducts surveying and mapping within the territory of the People's Republic of China must adopt the form of joint venture or of cooperation with a relevant department or unit of the People's Republic of China, and shall not involve any State secret and endanger the State security". ${ }^{36}$ The new provision contains some new changes in comparison with the old provision: (1) the original Article 19 has been moved ahead to be Article 7; (2) originally, such activity is only subject to the approval of the competent department of surveying and mapping administration under the State Council but now the approval is made by this department together with its counterpart in the Army; (3) Originally foreign organization or individual may conduct surveying and mapping alone within China's territory, but now such activity must be conducted in cooperation with the Chinese counterpart. It is noted that while some more restrictions are imposed, surveying and mapping by a foreign organization or individual may still be conducted alone after China's approval. Clearly, in China's eye, hydrographic surveying is not part of the freedoms of high seas.

The other reason for the revision of the Surveying and Mapping Law is connected to the implementation of the 1996 Regulations on the Management of the Foreign-Related Marine Scientific Research, which came into force from 1 October $1996 .{ }^{37}$ The Regulations apply to the conduct of survey activities by international organizations, organizations and individuals of any foreign country within sea areas under China's jurisdiction. It is recalled that in the Bowditch Incident, the Chinese side asked the Bowditch to stop its illegal

Activities in the Exclusive Economic Zone: Preventing Uncertainty and Defusing Conflict, 32 California Western International LaW Journal 294 (2002).

36 Article 7 of the 2002 amended Law of Surveying and Mapping, People's Daily (in Chinese), 1 September 2002, at 5. The amended Law was adopted on 29 August 2002 and came into force on 1 December 2002. The English version of the 1992 Law is available in Office of Policy, Law and Regulation, State Oceanic Administration (ed.), Collection of the Sea Laws and Regulations of the People's Republic of China 300-313 (2001).

37 It is reprinted in Gazette of the State Council of the People's Republic of China ${ }^{228-333 ~(1996) ~[i n ~ C h i n e s e] . ~ E n g l i s h ~ v e r s i o n ~ i s ~ a v a i l a b l e ~ i n ~ O f f i c e ~ o f ~ L a w, ~ P o l i c y ~}$ and Regulation. 
activities without China's approval in accordance with the above Regulations, but the American vessel only replied that it was doing military hydrographic surveying in international waters. When China addressed the issue to the American side through diplomatic channel, the United States responded that military surveying was not MSR so that it was not subject to the LOs Convention and to the approval of the coastal State. Clearly, China leant a lesson from this Incident that the relevant laws and regulations governing MSR did not work in practice with the Americans when they carried out military hydrographic surveying in China's jurisdictional waters.

Finally, if hydrographic surveying, whether military or civilian, was not considered part of MSR, then there should be a need to establish a new legal regime to govern it. As long as the grey area exists, problems regarding survey activities in the EEz between the coastal State and the conducting State will continue to arise. If hydrographic surveying can be regarded as part of MSR, military surveying could be then considered abuse of maritime rights of the law of the sea. It is interesting to note that two Chinese marine law enforcers revealed in their article that the Bowditch had applied to the Chinese authority for hydrographic surveying but due to some reasons its application was not approved. ${ }^{38}$

The Ministry of Land and Natural Resources adopted the Provisional Measures on the Management of Surveying and Mapping in China by Foreign Organizations or Individuals adopted on 20 November 2006 and the Measures took effect on 1 March 2007. ${ }^{39}$ Accordingly, any surveying and mapping in China including the sea areas within China's jurisdiction should be conducted through the cooperation with a Chinese partner either in the form of joint venture or cooperative project, subject to the prior approval of the Chinese competent authorities of both civilian and military surveying and mapping. Several surveying and mapping activities are excluded from such Sino-foreign cooperation. Ocean surveying and mapping is one of them. There are a few points which need to be highlighted: 1 . Although the Measures only use the term "other sea areas within the jurisdiction of the People's Republic of China", it is reasonably assume that China's EEz is included; 2. Unlike the Law of Surveying and Mapping, this Measures for the first time clearly provided that any such activity should be approved by the competent authorities from both the

38 You Zhiyong and Zhang Youfeng, Case Analysis of Foreign-Related Marine Law Enforcement in the East China Sea Zone, in Xiamen University Ocean Law Centre (ED.), Collected Papers of the Symposium in Commemorating the $20^{\text {th }}$ AnniverSary of the Adoption of the un Convention on the Law of the Sea 85 (2002)(in Chinese).

Text is available at http://www.gov.cn/ziliao/flfg/2007-01/22/content_503464.htm. 
government and the army; 3 . The exclusion of marine surveying and mapping implies that China has further tightened its laws and regulations on marine surveying and mapping, particularly in the consideration of military strategy as well as of natural resources information.

Military intelligence gathering and military hydrographic survey in the EEZ of another State remains a controversial issue in international law and invites hot debates, particularly between China and the United States. The Chinese usually argue that military intelligence gathering and military hydrographic survey in the EEz by foreign vessels and aircraft are not considered peaceful and thus violate the relevant provisions of the Los Convention. ${ }^{40}$ But in the US view, such activities are lawful, non-aggressive military activities consistent with the UN Charter, and can be conducted in the EEZ without the consent of the coastal State. ${ }^{41}$ Their different legal positions are reflected in their respective state practice as is once again demonstrated by the 2009 Impeccable Incident in the South China Sea. The Sino-American debate is still going on and it is hoped that the two sides could reach some degree of common understanding through their military consultation mechanism. ${ }^{42}$ It is reported that recently Chinese warships entered into the US EEZ near Guam, ${ }^{43}$ but it is not clear whether such warships simply enjoyed the freedom of navigation under international law, sailing through the US EEZ or conducted military activities such as intelligence gathering or military hydrographic surveying in the EEZ of the United States. It would be very interesting if the latter was the case.

From a legal perspective, two reasons can at least explain the controversy concerning military intelligence gathering and military hydrographic surveying in the EEz. First, the LOS Convention is not clear about whether hydrographic survey is part of the MSR, and some countries tend to separate it from the MSR regime. Second, the LOS Convention grants the EEZ a unique legal

40 See Moritaka Hayashi, Military Activities in the Exclusive Economic Zones of Foreign Coastal States, 27 International Journal of Marine ANd CoAstal LaW 801 (2012).

41 Hayashi, ibid., at 801.

42 As we know, the two sides concluded an agreement on military maritime safety consultation in 1998 and hold regular bilateral talks. Text of the agreement is available at http:// www.fas.org/nuke/control/sea/text/us-china98.htm.

43 See, Chinese Navy Begins US Economic Zone Patrols, 3 June 2013, available at http://johnib .wordpress.com/2013/o6/o3/chinee-navy-begins-us-economic -zone-patrols/. 
status, i.e., a maritime zone within national jurisdiction but subject to the freedoms of high seas, and there are differences in interpreting such freedoms in State practice as discussed partly in this article. It is perceived that the world community needs to find a way to conciliate different State practices in this respect and enhance peace, security and the rule of law in the ocean. The future possible review conference for the Los Convention should put this issue on its agenda to clarify the issue of military activities including military intelligence gathering and military hydrographic surveying in a foreign EEz. 